\title{
Molecular Imaging of Infection with Positron Emission Tomography: Beyond Fluorodeoxyglucose
}

\section{Enfeksiyonun Pozitron Emisyon Tomografi ile Moleküler Görüntülemesi: Florodeoksiglikoz Dışındaki Ajanlar}

\author{
Christopher J. Palestro
}

Hofstra Northwell Faculty of Medicine, Department of Radiology Hempstead, New York, USA

\begin{abstract}
Positron emission tomography (PET) with F-18 fluorodeoxyglucose (FDG) is an invaluable tool in the diagnostic workup of inflammatory and infectious diseases. FDG, however, is nonspecific, and is concentrated by malignant and benign neoplasm, as well as a variety of noninfectious inflammatory conditions. PET studies have important advantages over studies performed with single photon emitting radiopharmaceuticals and considerable effort has been devoted to the development of PET radiopharmaceuticals that are specific, or at least more specific than FDG, for infection. An early attempt at creating a more specific PET radiopharmaceutical was the development of a procedure for labeling autologous leukocytes with FDG. Although investigations have demonstrated improved specificity of FDG labeled leukocytes compared to FDG alone, with results comparable to those obtained with In-111 labeled leukocytes, there are issues with this test. Variability of labeling efficiency and stability of the FDG label, the short (110 minute) half -life of F-18, and the in vitro labeling procedure itself are obstacles to the widespread adoption of this procedure. The use of $\mathrm{Cu}-64$ as the radiolabel improves labeling efficiency and label stability, in vitro, but no clinical investigations have been conducted. The $\mathrm{Cu}-64$ neutrophil specific peptide, has shown promise in preclinical studies, but there have not been any clinical investigations of this agent. The radioiodinated thymidine analogue fialuridine (FIAU) has been investigated as an infection specific imaging radiopharmaceutical. Preclinical investigations were very promising, and an early pilot study using I-124 FIAU PET/
\end{abstract}

\section{Öz}

F-18 florodeoksiglikoz (FDG) işaretli pozitron emisyon tomografi (PET) enflamatuvar ve enfeksiyöz hastalıkların tanısında çok değerli bir yöntemdir. FDG, malign ve benign neoplazilerde olduğu kadar pek çok nonenfeksiyöz enflamatuvar durumda da tutulum gösterebildiğinden nonspesifik bir ajandır. PET ile yapılan çalışmaların tek foton emisyonu yapan radyofarmasötiklerle yapılanlara oranla pek çok avantajı vardır. Enfeksiyon görüntülemede spesifik ya da en azından FDG'den daha spesifik PET radyofarmasötikleri geliştirmek için yoğun çabalar sarf edilmiştir. Bunlardan ilki FDG ile otolog lökösitleri işaretlemeye dayalı prosedürdür. Araştırmalar FDG ile işaretli lökositlerin tek başına FDG'ye oranla spesifitelerinin daha yüksek ve sonuçlarının In-111 işaretli lökositlerle benzer olduğunu gösterse de bu testle ilgili sıkıntılar bulunmaktadır. İşaretleme etkinliğindeki ve FDG stabilitesindeki değişkenlikler, F-18'in kısa yarılanma ömrü (110 dakika) ve in vitro işaretleme prosedürünün kendisi bu prosedürün limitasyonlarıdır. İşaretleyici olarak Cu-64 kullanılması işaretleme etkinliğini ve stabilitesini iyileştirse de bununla ilgili yapılmış klinik çalışmalar bulunmamaktadır. Cu-64 nötrofil spesifik peptid ile klinik öncesi çalışmalarda umut verici sonuçlar alınmış olsa da bu ajanla yapılmış klinik çalışmalar yoktur. Radioiyodinize timidin analoğu olan fialuridin (FIAU) ile ilgili spesifik bir enfeksiyon görüntüleme ajanı olabileceğine dair çalışmalar yapılmıştır; preklinik veriler ve I-124 FIAU PET/bilgisayarlı tomografi ile yapılan pilot çalışmanın sonuçları oldukça umut verici olmuştur. Ancak devamında protez enfeksiyonları ve diyabetik ayak osteomiyeliti ile ilgili çalışmalarının sonuçları hayal kırıklığı 
CT yielded very encouraging results. Results of subsequent investigations for diagnosing prosthetic joint infection and diabetic pedal osteomyelitis were disappointing and the future of this agent is uncertain. The role of Ga-68 for imaging infection also is under investigation. Ga-68 citrate overcomes many of the disadvantages of Ga-67, but still suffers from a lack of specificity, and investigators have begun to focus their attention on complexing Ga-68 with siderophores and peptides in attempts to develop a more specific imaging agent. Preliminary results with these agents are very encouraging, but clinical trials are needed before their value can truly be ascertained.

Keywords: Fluorodeoxyglucose, fialuridine, Ga-68, leukocytes, peptides, positron emission tomography yaratmıştır, bu nedenle bu ajanın geleceği belirsizdir. Ga68 'in enfeksiyon görüntülemedeki rolü de araştırılan bir diğer konudur. Ga-68 sitrat, Ga-67'nin pek çok dezavantajının üstesinden gelse de spesifitesi oldukça düşüktür. Bu nedenle araştırmacılar Ga-68'i sideroforlar ve peptidler ile birleştirerek bu ajanı daha spesifik hale getirmeye çalışmaktadırlar. Bu ajanlarla yapılmış klinik öncesi çalışmaların sonuçları umut verici olmakla birlikte enfeksiyon görüntülemedeki önemini ispatlayacak klinik çalışmalar gerekmektedir.

Anahtar kelimeler: Florodeoksiglikoz, fialuridin, Ga-68, lökositler, peptidler, pozitron emisyon tomografi

\section{Introduction}

Positron emission tomography (PET) with F-18 fluorodeoxyglucose (FDG) has become an invaluable tool in the diagnostic workup of patients with a variety of inflammatory and infectious diseases. In spite of its usefulness, however, FDG is a nonspecific radiopharmaceutical that is concentrated by noninfectious conditions, including malignant and benign neoplasms, and a variety of noninfectious inflammatory conditions.

PET studies have important advantages over studies performed with single photon emitting radiopharmaceuticals. PET resolution is superior, which facilitates precise localization of abnormalities. Semi quantitative analysis, which is readily available with PET, but less feasible with conventional gamma camera imaging, potentially could be used to differentiating infectious from non-infectious conditions and for monitoring response to treatment. It is not surprising, therefore, that a considerable amount of effort has been devoted to the investigation and development of PET radiopharmaceuticals that are specific, or at least more specific than FDG, for infection.

\section{Fluorodeoxyglucose Labeled Leukocytes}

Perhaps the earliest attempt at creating a PET radiopharmaceutical more specific than FDG was the development of an in-vitro method for labeling autologous leukocytes. Nearly 25 years ago, Osman and Danpure demonstrated the feasibility of in vitro labeling of human leukocytes with FDG (1). They observed that
FDG uptake was dependent on the concentration of glucose in the labeling medium. Labeling efficiency decreased from $80 \%$, when the glucose concentration was $15 \mathrm{ug} / \mathrm{mL}$ to $2 \%$ when the glucose concentration was $1 \mathrm{mg} / \mathrm{mL}$. Cellular glucose retention depended on the extracellular concentration of glucose. In the absence of extracellular glucose, 91\% of the FDG remained in the leukocytes at one hour. When the extracellular glucose concentration was $1 \mathrm{mg} / \mathrm{mL}$, however, only $73 \%$ of the FDG remained in the cells at one hour.

Forstrom et al. reported their results for in vitro FDG labeling of human leukocytes (2). The labeling efficiency, approximately $80 \%$, was similar to what Osman and Danpure had reported (1). Eighty percent of the activity was in the granulocyte fraction, $14 \%$ in the mixed lymphocyte-plasma fraction and $6 \%$ was in plasma. FDG labeled leukocytes were stable in platelet-poor plasma for up to four hours. The trypan blue dye test indicated excellent cell viability after labeling. Forstrom et al. subsequently reported the results of biodistribution and dosimetry studies performed on four normal volunteers (3). The FDG-labeled leukocytes, as expected, were distributed primarily in the reticuloendothelial system. Cerebral and urinary tract activity also were present, however, presumably due to elution of FDG from the leukocytes. Whole body and major organ dosimetry estimates for FDG labeled leukocytes, with administered activity between 222- $252 \mathrm{MBq}(6-6.8 \mathrm{mCi})$ were comparable to the reported results for $\ln -111$ labeled leukocytes. 
Pellegrino et al. compared the uptakes of FDG labeled leukocytes and FDG in a rodent model of acute inflammation, with sterile turpentine, and bacterial infection, with Escherichia coli and Pseudomonas aeruginosa (4). They found markedly higher uptake of both radiopharmaceuticals in infected muscle compared to uninfected muscle. The average FDG labeled leukocyte infected to uninfected muscle ratios were approximately twice as high as the FDG ratios and FDG labeled leukocytes was superior to FDG for differentiating inflamed from normal tissue. The investigators concluded that FDG labeled leukocyte accumulation at sites of inflammation is not due only to accumulation of free FDG released from leukocytes.

Pio et al. compared FDG and FDG labeled leukocytes in mice and human subjects and found that the normal distribution pattern of the two radiopharmaceuticals was different (5). They demonstrated that FDG labeled leukocyte PET could serve as a quantitative marker for identifying both the presence and the severity of intestinal inflammation. In both murine and human subjects, they reported that there was little accumulation of FDG labeled leukocytes in the normal healthy gastrointestinal and urinary tracts. Intestinal foci of FDG-labeled leukocyte accumulation corresponded to areas of histopathologically or colonoscopically confirmed areas of inflamed bowel. Intensity of uptake correlated well with the degree of inflammation. These investigators concluded that FDG labeled leukocytes could provide noninvasive quantitative assessment of bowel inflammation quickly and accurately.

Dumarey et al. prospectively investigated 21 patients with FDG labeled leukocyte PET/computed tomography (CT) (6). The mean labeling efficiency was $75 \pm 21 \%$ (range 24-96\%). The mean stability of the label, in vitro, up to about four hours post labeling was $90 \%$. Imaging was performed approximately three hours after reinfusion of labeled cells. The FDG labeled leukocytes accumulated primarily in the reticuloendothelial system, which is similar to the distribution of other radiolabeled leukocytes. Sensitivity, specificity, and accuracy of FDG labeled leukocytes all were $86 \%$.

Rini et al. compared FDG labeled leukocyte imaging, using a gamma camera coincidence detection system, to In-111 labeled leukocyte imaging in 43 patients. Imaging was performed approximately two to six hours after reinfusion of 196-315 MBq FDG labeled leukocytes and approximately 24 hours after reinfusion of 17 $25 \mathrm{MBq}$ In-111 labeled leukocytes (7). The mean FDG labeling efficiency among the 43 patients, was $75 \pm 21 \%$, significantly lower $(p<0.0001)$ than the mean labeling efficiency for $\ln -111$, which was $90 \pm 5 \%$. Six additional patients were excluded from reinfusion of FDG labeled leukocytes because the labeling efficiency was less than $35 \%$. In contrast, the labeling efficiencies for In-111 in these six patients ranged from $89-93 \%$ (mean $90+2 \%$ ). Mean cell viability of FDG-labeled leukocytes was $98 \%$, which was comparable to the mean cell viability of $97 \%$ for In-111 labeled leukocytes. The accuracy of FDG labeled leukocytes (84\% [36/43]) was similar to that of In-111 labeled leukocytes (81\% [35/43]) and there was a high degree of concordance between the two tests.

Aksoy et al. investigated the role of FDG-labeled leukocyte PET/CT for diagnosing prosthetic joint infection (8). These investigators performed FDG labeled leukocyte PET/CT on 46 patients with positive FDG PET/CT studies. The mean labeling efficiency was $75 \pm 17 \%$. Labeled leukocyte viability testing was not performed. Patients underwent imaging $60-90$ minutes after reinfusion of 296-703 MBq (8-19 mCi) FDG labeled leukocytes. Since only patients with periprosthetic FDG uptake were included in the investigation, only the positive predictive value of the test, which was $27 \%$, could be calculated. In contrast, the positive predictive value of FDG labeled leukocyte PET/CT was $93.3 \%$. The sensitivity, specificity, and negative predictive values of FDG-labeled leukocyte PET/CT were 93.3\%, 97.4\%, and $97.4 \%$, respectively.

Bhattacharya et al. studied the role of FDG labeled leukocyte PET/CT for diagnosing infected fluid collections in patients with acute pancreatitis (9). The mean labeling efficiency was $81 \pm 10 \%$ (range: $31-97 \%$ ). Labeled leukocyte viability was more than $99 \%$ in all patients. Imaging was performed about two hours after reinfusion of the labeled cells. They reported that the test was $100 \%$ accurate for diagnosing infected fluid collections.

While the published results suggest that FDG labeled leukocytes is a useful infection imaging radiopharmaceutical, there are issues that need to be addressed if this procedure is to be incorporated into routine clinical use. One important issue is the variability of labeling efficiency for FDG labeled leukocytes, which has ranged from less than $25 \%$ to more than $90 \%$ $(6,7,8,9,10)$. Given this variability, how much activity should be used to label the cells? Does one assume a worst-case scenario, for example, a $25 \%$ labeling efficiency? What happens if the labeling efficiency is $90 \%$ ? Is the amount of activity reinfused reduced 
accordingly, and if so will the number of labeled cells reinfused be sufficient to provide diagnostically useful data?

Another issue is the stability of the FDG label. Published results vary. Dumarey et al. reported a mean stability of $90 \%$ up to about 4 hours after labeling (6). Bhargava et al. in contrast, reported a mean stability of $85 \pm 4 \%$ at one hour, which decreased to $68 \pm 7 \%$ at four hours (10). In comparison, the stability of In-111 labeled leukocytes, in the same subjects, was significantly higher at both time points, $94 \pm 2 \%$ at one hour and $91 \pm 3 \%$ at four hours.

Even assuming that the issues of labeling efficiency and label stability can be overcome, the 110-minute half-life of F-18 presents logistical problems, not easily overcome. The in vitro labeling process takes approximately two three hours, so this time needs to be accounted for when determining the amount of activity used to label the cells. The 110-minute half-life of F-18 makes it impractical for labeling to be performed offsite, which means that the test would be limited to those sites capable of performing labeling. This is a significant limitation in the United States where the vast majority of leukocyte labeling procedures are performed in outside radiopharmacies. Delayed (e.g. 24 hours post injection) imaging may occasionally be desirable. The short halflife of F-18, however, precludes imaging much later than 4-5 hours after injection.

\section{Cu-64 Labeled Leukocytes}

The ideal radionuclide for labeling leukocytes should have a consistently high labeling efficiency while preserving cell viability. The radiolabel should be stable, with as little elution of radioactivity from the cells as possible. The physical half-life of the radionuclide should be sufficiently long to make the in vitro labeling procedure practical and to allow for delayed imaging. Cu-64 is an intermediate half-lived positron emitting radionuclide with a half-life of approximately 13 hours. Bhargava et al. investigated the potential of this radionuclide for labeling leukocytes in vitro (10). They labeled human leukocytes in vitro with $\mathrm{Cu}-64$ and compared labeling efficiency, cell viability and stability of $\mathrm{Cu}$ labeled leukocytes with those of In-111 labeled leukocytes and FDG labeled leukocytes in the same subjects. The mean labeling efficiency for Cu-64 labeled leukocytes, $87 \pm 4 \%$, was similar to that for In-111 labeled leukocytes (86 $\pm 4 \%)$. Labeling efficiencies for both were significantly higher than the labeling efficiency for FDG labeled leukocytes (60 $\pm 19 \%)$. Cell viabilities for all three were similar at 1 hour, and significantly higher for $\mathrm{Cu}$ labeled leukocytes at three and 24 hours. Label stability was always significantly higher for In-111 labeled leukocytes than for Cu-64 and FDG labeled leukocytes. These results suggest that $\mathrm{Cu}-64$ labeled leukocytes might be useful for imaging infection, but there have been no clinical investigations to date.

Regardless of the radionuclide used, the in-vitro labeling procedure is labor intensive, technically demanding, requires skilled personnel, not always available, and requires direct contact with blood. It is not always possible to label enough leukocytes to obtain diagnostically useful images in the profoundly leukopenic or very young patient. Locke et al. labeled a neutrophil specific peptide, cFLFLFK-PEG, with $\mathrm{Cu}$ 64 (11). This peptide is an antagonist to the neutrophil formyl peptide receptor. In vitro, the radiolabeled peptide had a high binding affinity for human neutrophils and, importantly, did not exert any biologic effects on the cells themselves. They also studied this agent in a murine model of Klebsiella pneumonia. Imaging was performed approximately 18 hours after injection of the labeled peptide. Average lung SUV for Klebsiellainfected mice was $0.142 \pm 0.054$ versus $0.028 \pm 0.003$ for controls $(p<0.003)$. Although the preclinical data were encouraging, to date no human studies with this agent have been conducted.

\section{I-124 Fialuridine}

The radioiodinated thymidine analogue fialuridine (FIAU) was developed for reporter genes, for cells that were transfected with herpes simplex virus thymidine kinase (TK). This enzyme transfers a phosphate group from ATP to pyrimidine deoxynucleoside. The lipophilic agent diffuses into the cell where it is trapped with the TK activity, because the phosphorylated tracer cannot pass the plasma membrane (12). Bettegowda et al. demonstrated that the TKgene of bacteria was sufficiently similar to that of the viral TK and that FIAU could also be phosphorylated by endogenous bacterial TK (13). In their investigation, FIAU inhibited wild-type bacterial growth, but had no effect on TK-deficient bacterial growth. Using the single photon emitting I-125 labeled FIAU, they successfully imaged bacterial infections in mice. Uptake in foci of infection was identified within four hours after radiopharmaceutical administration. The authors speculated that activity remained in infected tissues because I-125 FIAU was incorporated into the bacterial DNA. Activity in uninfected tissue, however, decreased over time, resulting in high target to background ratios by 48 hours after radiopharmaceutical administration. 
Pullambhatla et al. investigated the role of I-125 FIAU imaging in murine bacterial pulmonary infection (14). Uptake in infected lungs was present at two hours post injection and was significantly higher than uptake in infected than inflamed uninfected and control lungs. There was a significant decrease in pulmonary uptake following antibiotic treatment. The investigators suggested that radiolabeled FIAU bacterial imaging might be useful to facilitate the development of new antibiotics in preclinical models.

Diaz et al. conducted a pilot investigation of I-124 FIAU PET/CT for diagnosing musculoskeletal infection in nine subjects including eight with suspected infection and one healthy control (15). None of the subjects received antibiotic treatment for at least three weeks prior to imaging. All seven patients with musculoskeletal infection demonstrated radiopharmaceutical uptake at the site of infection within two hours after injection. There was no abnormal uptake in one subject without infection or in the one control. There were no adverse reactions among any of the nine subjects.

Results of subsequent investigations of I-124 FIAU for diagnosing musculoskeletal infection, however, have been disappointing. Zhang et al. prospectively investigated the role of I-124 FIAU for diagnosing lower extremity joint arthroplasty infection in 19 subjects, all of whom underwent surgery within thirty days after imaging (16). Three of the 19 had a final diagnosis of infection. Imaging was performed at two and twenty fours after radiopharmaceutical administration. Interpretation of the PET/CT images was hampered by metal induced attenuation correction artifacts. On the uncorrected PET images, there was diffuse, pronounced muscle uptake. None of the semiquantitative measures used, which included target-to-background ratio $S U V_{\text {max }}$, $S U V_{\text {mean }}$ and $S U V_{\text {peak }}$, were useful for differentiating infected from uninfected prostheses. The authors concluded that the utility of I-124 FIAU in the detection of prosthetic joint infection is limited by suboptimal image quality due to metal artifact and high nonspecific muscle uptake. The results of an investigation of I-124 FIAU for diagnosing pedal osteomyelitis in diabetics also were disappointing. The study was terminated because of a lack of correlation between I-124 FIAU uptake and bone biopsy results (17).

\section{Ga-68}

For nearly fifty years, Ga-67 citrate has been used for imaging infection. There are, however, significant disadvantages to this radiopharmaceutical, which include nonspecific uptake in aseptic inflammation, tumors, and trauma. Image quality, even when performed as a singlephoton emission computed tomography/CT study is suboptimal and the interval between administration and imaging usually is 48 to 72 hours. Now that the positron emitter Ga-68 is more widely available, investigators are studying the role of this radionuclide for diagnosing infection. Kumar et al. studied the role of Ga-68 citrate in the diagnosis of a Staphylococcus aureus infection in rodents (18). Moderate radiopharmaceutical uptake was present within five minutes after injection. There was intense focal uptake from thirty minutes to six hours post injection. They also studied one patient with a postoperative intraabdominal infection and observed that the test was positive within thirty minutes after injection. In a pilot study of patients with tuberculosis, Ga-68 accumulated in pulmonary and extra-pulmonary tuberculous lesions and was superior to $\mathrm{CT}$ for detecting extra-pulmonary disease. The authors concluded that Ga-68 might be useful for differentiating active from inactive disease and for monitoring treatment response (19).

Nanni et al. performed $40 \mathrm{Ga}-68$ citrate PET/CT on 31 patients suspected of having musculoskeletal infection (20). Imaging was performed approximately one hour after radiopharmaceutical administration. All 23 cases of musculoskeletal infection were positive. Four of 17 cases without infection also were positive. All four false positive results were due to tumor. Sensitivity, specificity, accuracy, positive predictive and negative predictive value were $100 \%, 76 \%, 90 \%, 85 \%$, and $100 \%$, respectively.

Although Ga-68 citrate reduces or eliminates some of the disadvantages of Ga-67 citrate, such as poor image quality and the long interval between administration and imaging, it still suffers from limited specificity $(20,21)$. As a result, other investigators have turned their attention to complexing Ga-68 with peptides in attempts to develop more specific imaging agents (22). Vascular adhesion protein 1 (VAP-1) is a human endothelial protein that is expressed on cell surfaces under inflammatory conditions. Lankinen et al. postulated that Ga-68 labeled 1,4,7,10-tetraazacyclododecane- $\mathrm{N}^{\prime}$, $\mathrm{N}^{\prime \prime}, \mathrm{N}^{\prime \prime \prime}, \mathrm{N}^{\prime \prime \prime}$-'tetraacetic acid-peptide targeted to VAP1 (Ga-68 DOTAVAP-P1) could be useful for imaging early inflammation and infection in healing bones (23). These investigators compared Ga-68 DOTAVAP-P1 PET in 68 rats, including 34 with uninfected healing cortical bone defects and 34 with Staphylococcus aureus osteomyelitis. There was no significant difference in 
the mean grade of VAP- 1 expression at 24 hours and seven days ( $1.10 \pm 0.39$ and $1.00 \pm 0.47$, respectively) in animals with healing cortical bone defects. The mean grade of VAP-1 expression in osteomyelitic animals was significantly higher $(p=0.0330)$ at seven days $(2.85 \pm 0.34)$ than at 24 hours $(2.39 \pm 0.49)$. VAP-1 expression levels were significantly higher $(p<0.0001)$ in infected animals than in the animals with healing bone defects at both time points. Ga-68 DOTAVAP-P1 uptake was similar in osteomyelitis and the healing cortical bone defects during the first 36 hours after surgery. Beyond 36 hours, uptake was observed only in infected bones. Ga-68 DOTAVAP-P1 uptake was significantly higher $(p<0.0001)$ in the infected bones at 7 days. The authors concluded that Ga-68 DOTAVAP-P1 accurately demonstrates the inflammatory phase in healing bones and the progress of infection in osteomyelitic bones, facilitating the differentiation of bone infection due to Staphylococcus aureus and normal bone healing within seven days after onset. Ujula et al. performed Ga-68 DOTAVAP-P1 PET on healthy rats and rats with Staphylococcus aureus osteomyelitis of the tibia (24). Radiopharmaceutical uptake in osteomyelitis was compared with negative control peptide and competition with an excess of unlabeled DOTAVAP-P1. Ga-68 DOTAVAP-P1 was more efficiently bound to VAP-1-transfected cells than to controls. The agent was rapidly cleared from the circulation, excreted quickly in urine and had an in vivo half-life of $26 \pm 2.3$ minute. Infected bones demonstrated a modest target-to-background ratio. Compared to Ga-68 DOTAVAP-P1, studies with the negative control peptide and competitors revealed significantly lower uptake at the site of infection. The authors concluded that the results of this investigation represented a proofof-concept that infection-induced VAP-1 can be targeted by Ga-68 DOTA peptide.

The uptake mechanisms of Ga-67 in infection are complex and not well understood. It is believed that siderophores, which are gallium avid low molecular weight chelating agents produced by bacteria, are involved (25). The potential of Ga-68 labeled siderophores for imaging infection has been investigated $(26,27,28)$. Petrik et al. conducted in vitro and in vivo investigations of several Ga-68 labeled siderophores using Aspergillus fumigatus cultures (26). Uptake in the cultures depended on iron load and siderophore type. In mice, there was rapid blood clearance and renal excretion of Ga-68 triacetylfusarinine C (TAFC) and Ga68 ferrioxamine $E$ (FOXE). Furthermore these two agents bound Ga-68 with high affinity and stability, low protein binding and high affinity and specificity for Aspergillus fumigatus. These results suggest that these two agents may be useful for imaging Aspergillus infection. In a rat model of Aspergillus lung infection, Petrik et al. demonstrated highly selective uptake of both Ga-68 TAFC and Ga-68 FOXE in infected lung tissue and good correlation with disease severity (27).

Petrik et al. investigated the specificity of Ga-68 TAFC and Ga-68 FOXE. In vitro uptake of these two radiopharmaceuticals was examined in various fungal, bacterial and yeast cultures and human lung cancer (H1299) cells (28). In vivo imaging was performed in fungal and bacterial rat infection and inflammation models. There was rapid accumulation of Ga-68 TAFC and Ga-68 FOXE in A. fumigatus cultures, with significantly less uptake in other fungal species and minimal uptake in other microorganisms and $\mathrm{H} 1299$ cells, with the exception of Ga-68-FOXE uptake in Staphylococcus aureus. There was rapid uptake of both agents in the lungs of A. fumigatus-infected rats, low accumulation in sterile inflammation and no uptake in bacterial abscesses. Ga-68 FOXE was more sensitive, while Ga-68 TAFC was more specific.

Antimicrobial peptides are an important component of the natural defenses of most living organisms. Most are small, cationic and amphipathic (hydrophilic and hydrophobic) and attack pathogens by multiple mechanisms. They exhibit broad-spectrum activity against Gram-positive and Gram-negative bacteria, yeasts, fungi and enveloped viruses. They also are involved in apoptosis, wound healing, and immune modulation (29). While most investigations of antimicrobial peptides have used Tc- $99 \mathrm{~m}$ as the radiolabel, the potential of Ga-68 labeled antimicrobial peptides as infection specific imaging compounds is now being investigated $(30,31,32)$. Ebenhan et al. labeled the UBI29-41 fragment of ubiquicidin with Ga-68, and compared uptake of this agent in staph aureus muscle infection, turpentine induced muscle inflammation, and ovalbumin induced lung inflammation in rabbits (31). $\mathrm{PET} / \mathrm{CT}$ was performed at intervals up to two hours post injection. Infected thigh muscle could be clearly differentiated from sterile inflamed thigh muscle. Uptake in the ovalbumin-induced inflammation of the lungs was insignificant. These results suggest that Ga-68 labeled UBI29-41 potentially could differentiate infection from sterile inflammation.

Recently, Mokaleng et al. investigated the potential of an antimicrobial peptide derivative, TBIA101 that was conjugated to DOTA and radiolabeled with Ga-68 
for imaging infection (32). Ga-68 DOTA-TBIA101 micro$\mathrm{PET} / \mathrm{CT}$ was performed on $\mathrm{E}$. coli muscle infection in mice. Radiopharmaceutical uptake was significantly higher $(p=0.333)$ in infected thigh muscle compared to uninfected thigh muscle, forearm muscle $(p=0.092)$, and background $(p=0.021)$. Ga-68 DOTA-TBIA101 clearly localized the infection site, with no notable uptake in the contralateral muscle.

\section{Conclusion}

The value of FDG-PET in the diagnostic workup of patients with infection and inflammation is now well established. The most significant limitation to this radiopharmaceutical is lack of specificity. Investigators have sought both to capitalize on the advantages that PET offers compared to single photon emitting radiopharmaceuticals, and to develop PET radiopharmaceuticals with improved specificity for infection. Initial investigations focused on in-vitro labeling of leukocytes with PET radionuclides. Although published results have been encouraging, these agents, for a variety of reasons, have not enjoyed widespread use, nor is it likely that they will. Furthermore, while labeled leukocytes are specific for leukocyte migration, they are not truly specific for infection. Initial results with I-124 FIAU, thought to be infection specific, were encouraging, but more recent data have dampened enthusiasm for this agent. Preliminary results with Ga68 labeled siderophores and antimicrobial peptides are exciting, but clinical trials are needed before their value can truly be ascertained.

\section{References}

1. Osman S, Danpure HJ. The use of 2-[18F]Fluoro-2-deoxyD-glucose as a potential in vitro agent for labelling human granulocytes for clinical studies by positron emission tomography. Nucl Med Biol 1992;19:183-190.

2. Forstrom LA, Mullan BP, Hung JC, Lowe VJ, Thorson LM. 18-FDG labeling of human leukocytes. Nucl Med Commun 2000;21:691-694.

3. Forstrom LA, Dunn WL, Mullan BP, Hung JC, Lowe, VJ, Thorson LM. Biodistribution and dosimetry of 18Ffluorodeoxyglucose labeled leukocytes in normal human subjects. Nucl Med Commun 2002;23:721-725.

4. Pellegrino D, Bonab AA, Dragotakes SC, Pitman JT, Mariani G, Carter EA. Inflammation and infection: Imaging properties of 18F-FDG-labeled white blood cells versus 18F-FDG. J Nucl Med 2005;46:1522-1530.

5. Pio BS, Byrne FR, Aranda R, et al. Noninvasive quantification of bowel inflammation through positron emission tomography imaging of 2-deoxy-2-2[18F]fluoro-D-glucose-labeled white blood cells. Mol Imaging Biol 2003;5:271-277.

6. Dumarey N, Egrise $D$, Blocklet $D$, et al. Imaging infection with 18F-FDG-labeled leukocyte PET/CT: initial experience in 21 patients. J Nucl Med 2006;47:625-632.

7. Rini JN, Bhargava KK, Tronco GG, et al. PET with FDGlabeled leukocytes versus scintigraphy with 111 In-oxinelabeled leukocytes for detection of infection. Radiology 2006;238:978-987.

8. Aksoy SY, Asa S, Ozhan M, et al. FDG and FDG-labelled leucocyte PET/CT in the imaging of prosthetic joint infection. Eur J Nucl Med Mol Imaging 2014;41:556-564.

9. Bhattacharya A, Kochhar R, Sharma S, et al. PET/CT with 18F-FDG-labeled autologous leukocytes for the diagnosis of infected fluid collections in acute pancreatitis. J Nucl Med 2014;55:1267-1272.

10. Bhargava KK, Gupta RK, Nichols KJ, Palestro CJ. In-vitro human leukocyte labeling with (64)Cu: an intraindividual comparison with (111)In-oxine and 18F-FDG. Nucl Med Biol 2009;36:545549.

11. Locke LW, Chordia MD, Zhang Y, et al. A novel neutrophilspecific PET imaging agent: cFLFLFK-PEG-64Cu. J Nucl Med 2009;50:790-797.

12. Boerman OC, Laverman P, Oyen WJ. FIAU: from reporter gene imaging to imaging of bacterial proliferation. Am J Nucl Med Mol Imaging 2012;2:271-272.

13. Bettegowda C, Foss CA, Cheong I, et al. Imaging bacterial infections with radiolabelled 1-(2'-deoxy-2'fluoro- $\beta$-Darabinofurasonyl)-5-iodouracil. Proc Natl Acad Sci U S A 2005;102:1145-1150.

14. Pullambhatla M, Tessier J, Beck G, Jedynak B, Wurthner JU, Pomper MG. [125I]FIAU imaging in a preclinical model of lung infection : quantification of bacterial load. Am J Nucl Med Mol Imaging 2012;2:260-270.

15. Diaz LA Jr, Foss CA, Thornton $K$, et al. Imaging of musculoskeletal bacterial infections by [124I]FIAU-PET/CT. PLoS One 2007;10:e1007.

16. Zhang XM, Zhang HH, McLeroth $P$, et al. [124I]FIAU: Human dosimetry and infection imaging in patients with suspected prosthetic joint infection. Nucl Med Biol 2016;43:273-279.

17. [124I]FIAU-PET/CT scanning in diagnosing osteomyelitis in patients with diabetic foot infection.clinicaltrials.gov/ct2/ show/NCT01764919. Updated April 6, 2016. Accessed August 13, 2016.

18. Kumar V, Boddeti DK, Evans SG, Angelides S. (68)Ga-citrate-PET for diagnostic imaging of infection in rats and for intra-abdominal infection in a patient. Curr Radiopharm 2012;5:71-75.

19. Vorster M, Maes A, Van de Wiele C, Sathekge MM. 68Gacitrate PET/CT in Tuberculosis: A pilot study. Q J Nucl Med Mol Imaging 2014 Mar 20. [Epub ahead of print]

20. Nanni C, Errani C, Boriani L, et al. 68Ga-citrate PET/CT for evaluating patients with infections of the bone: preliminary results. J Nucl Med 2010;51:1932-1936. 
21. Vorster M, Maes A, Jacobs A, et al. Evaluating the possible role of $68 \mathrm{Ga}$-citrate $\mathrm{PET} / \mathrm{CT}$ in the characterization of indeterminate lung lesions. Ann Nucl Med 2014;28:523-530.

22. Roivainen A, Jalkanen S, Nanni C. Gallium-labelled peptides for imaging of inflammation. Eur J Nucl Med Mol Imaging 2012;39(Suppl 1):68-77.

23. Lankinen P, Mäkinen TJ Pöyhönen TA, et al. (68)GaDOTAVAP-P1 PET imaging capable of demonstrating the phase of inflammation in healing bones and the progress of infection in osteomyelitic bones. Eur J Nucl Med Mol Imaging 2008;35:352-364.

24. Ujula T, Salomäkia S, Virsua P, et al. Synthesis, 68Ga labeling and preliminary evaluation of DOTA peptide binding vascular adhesion protein-1: a potential PET imaging agent for diagnosing osteomyelitis. Nucl Med Biol 2009;36:631-641.

25. Palestro $\mathrm{CJ}$. Continuing education on radionuclide imaging of musculoskeletal infection: a review. J Nucl Med 2016.

26. Petrik M, Haas H, Schrettl M, Helbok A, Blatzer M, Decristoforo C. In vitro and in vivo evaluation of selected $68 \mathrm{Ga}$-siderophores for infection imaging. Nucl Med Biol 2012;39:361-369.

27. Petrik $M$, Franssen $G M$, Haas $H$, et al. Preclinical evaluation of two 68Ga-siderophores as potential radiopharmaceuticals for Aspergillus fumigatus infection imaging. Eur J Nucl Med Mol Imaging 2012;39:1175-1183.

28. Petrik $\mathrm{M}, \mathrm{Haas} \mathrm{H}$, Laverman $\mathrm{P}$, et al.68Ga-triacetylfusarinine $\mathrm{C}$ and $68 \mathrm{Ga}$-ferrioxamine $\mathrm{E}$ for Aspergillus infection imaging: uptake specificity in various microorganisms. Mol Imaging Biol 2014;16:102-108.

29. Wang G. Human antimicrobial peptides and proteins. Pharmaceuticals (Basel) 2014;7:545-594.

30. Ebenhan T, Chadwick N, Sathekge MM, et al. Peptide synthesis, characterization and ${ }^{68} \mathrm{Ga}$-radiolabeling of NOTA-conjugated ubiquicidin fragments for prospective infection imaging with PET/CT. Nucl Med Biol 2014;41:390400.

31. Ebenhan T, Zeevaart JR, Venter JD, et al. Preclinical evaluation of 68Ga-labeled 1,4,7-triazacyclononane-1,4,7-triacetic acidubiquicidin as a radioligand for PET infection imaging. J Nucl Med 2014;55:308-314.

32. Mokaleng BB, Ebenhan T, Ramesh S, et al. Synthesis, 68Garadiolabeling, and preliminary in vivo assessment of a depsipeptide-derived compound as a potential PET/CT infection imaging agent. Biomed Res Int 2015;2015:284354. 


\section{Enfeksiyonun Pozitron Emisyon Tomografi ile Moleküler Görüntülemesi: Florodeoksiglikoz Dışındaki Ajanlar Molecular Imaging of Infection with Positron Emission Tomography: Beyond Fluorodeoxyglucose}

Christopher J. Palestro

Hofstra Northwell Tıp Fakültesi, Radyoloji Anabilim Dalı, New York, ABD

Çevirmen: Evrim Sürer Budak

Antalya Kamu Hastaneleri Birliği Sağlık Bilimleri Üniversitesi, Antalya Eğitim ve Araştırma Hastanesi, Nükleer Tıp Kliniği, Antalya, Türkiye

\section{Öz}

F-18 florodeoksiglikoz (FDG) işaretli pozitron emisyon tomografi (PET) enflamatuvar ve enfeksiyöz hastalıkların tanısında çok değerli bir yöntemdir. FDG, malign ve benign neoplazilerde olduğu kadar pek çok nonenfeksiyöz enflamatuvar durumda da tutulum gösterebildiğinden nonspesifik bir ajandır. PET ile yapılan çalışmaların tek foton emisyonu yapan radyofarmasötiklerle yapılanlara oranla pek çok avantajı vardır. Enfeksiyon görüntülemede spesifik ya da en azından FDG'den daha spesifik PET radyofarmasötikleri geliştirmek için yoğun çabalar sarf edilmiştir. Bunlardan ilki FDG ile otolog lökösitleri işaretlemeye dayalı prosedürdür. Araştırmalar FDG ile işaretli lökositlerin tek başına FDG'ye oranla spesifitelerinin daha yüksek ve sonuçlarının In-111 işaretli lökositlerle benzer olduğunu gösterse de bu testle ilgili sıkıntılar bulunmaktadır. İşaretleme etkinliğindeki ve FDG stabilitesindeki değişkenlikler, F-18'in kısa yarılanma ömrü (110 dakika) ve in vitro işaretleme prosedürünün kendisi bu prosedürün limitasyonlarıdır. İşaretleyici olarak Cu-64 kullanılması işaretleme etkinliğini ve stabilitesini iyileştirse de bununla ilgili yapılmış klinik çalışmalar bulunmamaktadır. Cu-64 nötrofil spesifik peptid ile klinik öncesi çalışmalarda umut verici sonuçlar alınmış olsa da bu ajanla yapılmış klinik çalışmalar yoktur. Radioiyodinize timidin analoğu olan fialuridin (FIAU) ile ilgili spesifik bir enfeksiyon görüntüleme ajanı olabileceğine dair çalışmalar yapılmıştır; preklinik veriler ve I-124 FIAU PET/bilgisayarlı tomografi ile yapılan pilot çalışmanın sonuçları oldukça umut verici olmuştur.

\begin{abstract}
Positron emission tomography (PET) with F-18 fluorodeoxyglucose (FDG) is an invaluable tool in the diagnostic workup of inflammatory and infectious diseases. FDG, however, is nonspecific, and is concentrated by malignant and benign neoplasm, as well as a variety of noninfectious inflammatory conditions. PET studies have important advantages over studies performed with single photon emitting radiopharmaceuticals and considerable effort has been devoted to the development of PET radiopharmaceuticals that are specific, or at least more specific than FDG, for infection. An early attempt at creating a more specific PET radiopharmaceutical was the development of a procedure for labeling autologous leukocytes with FDG. Although investigations have demonstrated improved specificity of FDG labeled leukocytes compared to FDG alone, with results comparable to those obtained with In-111 labeled leukocytes, there are issues with this test. Variability of labeling efficiency and stability of the FDG label, the short (110 minute) half -life of F-18, and the in vitro labeling procedure itself are obstacles to the widespread adoption of this procedure. The use of $\mathrm{Cu}-64$ as the radiolabel improves labeling efficiency and label stability, in vitro, but no clinical investigations have been conducted. The Cu-64 neutrophil specific peptide, has shown promise in preclinical studies, but there have not been any clinical investigations of this agent. The radioiodinated thymidine analogue fialuridine (FIAU) has been investigated as an infection specific imaging
\end{abstract}


Ancak devamında protez enfeksiyonları ve diyabetik ayak osteomiyeliti ile ilgili çalışmalarının sonuçları hayal kırıklığı yaratmıştır, bu nedenle bu ajanın geleceği belirsizdir. Ga68 'in enfeksiyon görüntülemedeki rolü de araştırılan bir diğer konudur. Ga-68 sitrat, Ga-67'nin pek çok dezavantajının üstesinden gelse de spesifitesi oldukça düşüktür. Bu nedenle araştırmacılar Ga-68'i sideroforlar ve peptidler ile birleştirerek bu ajanı daha spesifik hale getirmeye çalışmaktadırlar. Bu ajanlarla yapılmış klinik öncesi çalışmaların sonuçları umut verici olmakla birlikte enfeksiyon görüntülemedeki önemini ispatlayacak klinik çalışmalar gerekmektedir.

Anahtar kelimeler: Florodeoksiglikoz, fialuridin, Ga-68, lökositler, peptidler, pozitron emisyon tomografi radiopharmaceutical. Preclinical investigations were very promising, and an early pilot study using I-124 FIAU PET/ CT yielded very encouraging results. Results of subsequent investigations for diagnosing prosthetic joint infection and diabetic pedal osteomyelitis were disappointing and the future of this agent is uncertain. The role of Ga-68 for imaging infection also is under investigation. Ga-68 citrate overcomes many of the disadvantages of Ga-67, but still suffers from a lack of specificity, and investigators have begun to focus their attention on complexing Ga-68 with siderophores and peptides in attempts to develop a more specific imaging agent. Preliminary results with these agents are very encouraging, but clinical trials are needed before their value can truly be ascertained.

Keywords: Fluorodeoxyglucose, fialuridine, Ga-68, leukocytes, peptides, positron emission tomography

\%2'ye düşmektedir. Hücre içi glikoz retansiyonu glikozun ekstraselüler konsantrasyonuna bağlıdır. Ekstrasellüler glikoz yokluğunda ilk 1 saatte FDG'nin \%92'si lökositlerce tutulmaktadır. Ekstraselüler glikoz konsantrasyonunun 1 $\mathrm{mg} / \mathrm{mL}$ olması halinde ise bu oran \%73'e düşmektedir. Forstrom ve ark.'da insan lökositlerinin in vitro FDG işaretlemesi hakkındaki çalışmalarında Osman ve Danpure ile benzer şekilde işaretleme etkinliğini \%80 olarak bulmuşlardır $(1,2)$. Aktivitenin $\% 80$ 'inin granülosit fraksiyonunda, \%14'ünün miks lenfosit-plazma fraksiyonunda ve $\% 6$ 'sının plazma fraksiyonunda olduğu gösterilmiştir. FDG işaretli lökositler trombositten fakir plazmada 4 saate kadar stabil kalabilmişlerdir. Tripan mavi boya testi ile işaretleme sonrası hücre canlılığı mükemmel şekilde gösterilmiştir. Forstrom ve ark. bu çalışmayı takiben, 4 normal gönüllüden oluşan çalışmalarında biyodistribüsyon ve dozimetri sonuçlarını değerlendirmişlerdir (3). Buna göre; beklendiği üzere FDG işaretli lökositler primer olarak retiküloendotelyal sistemde dağılım göstermişlerdir. Ayrıca, büyük intimalle FDG'nin lökositlerden elüsyonuna bağlı olarak serebral ve üriner sistem aktivitesi de gözlenmiştir. FDG işaretli lökositler ile 222-252 MBq (6-6,8 mCi) aktivite uygulanması sonucu tüm vücut ve major organ dozimetre sonuçları In-111 ile elde edilen sonuçlarla benzer bulunmuştur (3).

Pellegrino ve ark. FDG işaretli lökosit ve FDG'ye ait tutulumları kemirgenlerde steril terebentin ile oluşturulan akut enflamasyon ve Escherichia coli ve Pseudomonas aeruginosa ile oluşturulan bakteriyel etkinliği, glikoz konsantrasyonu $1 \mathrm{mg} / \mathrm{mL}$ olduğunda 
enfeksiyon modelinde karşılaştırmışlardır. Her iki radyofarmasötiğin tutulumu da enfekte kas dokusunda enfekte olmayana oranla belirgin artmış olarak bulunmuştur. Ortalama enfekte kas/enfekte olmayan kas tutulum oranı FDG işaretli lökosit ile FDG'ye oranla yaklaşık iki kat daha yüksek bulunmuştur. Ayrıca FDG işaretli lökositlerin enflame dokuyu normal dokudan ayırmada FDG'ye oranla daha üstün olduğu gösterilmiştir. Araştırmacılar; enflamasyon alanındaki FDG işaretli lökosit akümülasyonunun sadece lökositlerden salınan serbest FDG'ye bağlı olmadığı sonucuna varmışlardır. Pio ve ark. FDG işaretli lökositler ile FDG'yi insan ve fare modelinde karşılaştırmışlar ve bu iki radyofarmasötiğin normal dağılım paterninin farklı olduğu sonucunu bulmuşlardır (5). FDG işaretli lökosit PET'in intestinal enflamasyon varlığını ve ciddiyetini saptamada kantitatif bir belirteç olabileceği sonucuna varmışlardır. Hem farelerde hem de insanlarda normal sağlıklı gastrointestinal ve üriner traktta az miktarda FDG işaretli lökosit akümülasyonu olabileceğini ve FDG işaretli lökosit ile saptanan fokal intestinal odakların histopatolojik olarak veya kolonoskopik olarak konfirme edilen enflame barsak alanlarına karşılık geldiğini bildirmişlerdir. Tutulumun intensitesi de enflamasyonun şiddeti ile korelasyon göstermektedir. Araştırmacılar FDG işaretli lökositler ile barsak enflamasyonunun hızlı ve doğru bir şekilde, noninvaziv ve kantitatif olarak değerlendirilebileceği sonucuna varmışlardır.

Dumarey ve ark. FDG işaretli lökosit yöntemi ile 21 hastayı prospektif olarak değerlendirmişler ve ortalama işaretleme etkinliğini \%75 \pm 21 (\%24-96) olarak bulmuşlardır (6). Ortalama in vitro stabilite işaretlemeden sonraki 4 saate kadar $\% 90$ olarak saptanmıştır. Görüntüleme, işaretlenen hücrelerin tekrar enjeksiyonundan yaklaşık 3 saat sonra gerçekleştirilmiştir. Diğer radyoişaretli lökositlerde olduğu gibi FDG işaretli lökositler de primer olarak retiküloendotelyal sistemde akümüle olmuşlardır. FDG işaretli lökositlerin sensitivite, spesifite ve doğruluğu \%86 olarak bulunmuştur.

Rini ve ark. 43 hastada, FDG işaretli lökosit görüntülemeyi bir gama kamera koinsidans sistemi kullanarak In-111 işaretli lökosit görüntüleme yöntemi ile karşılaştırmışlardır (7). Görüntülemeye 196-315 MBq FDG işaretli lökosit enjeksiyonundan yaklaşık 2 ile 6 saat; 17-25 MBq In-111 işaretli lökosit enjeksiyonundan yaklaşık 24 saat sonra başlanmıştır. Kırk üç hastada, ortalama FDG işaretleme etkinliği $\% 75 \pm 21$ ile ortalama işaretlenme etkinliği \%90 \pm 5 olan In-111'e oranla anlamlı olarak daha düşük bulunmuştur $(p<0,0001)$. FDG işaretli lökosit grubundan altı hasta işaretlenme etkinliğinin \%35'in altında olmasından dolayı çalışma dışı bırakılmıştır. Tersine bu altı hastada In-111 işaretleme etkinliği \%8993 (ortalama \%90 \pm 2 ) arasında bulunmuştur. FDG işaretli lökositler için ortalama hücre canlılığı \%98 ile ortalama hücre canlılı̆ı \%81 (5/43) olan In-111 işaretli lökositler ile benzer bulunmuş ve bu iki test arasında yüksek ölçüde uyum saptanmıştır.

Aksoy ve ark. protez enfeksiyonlarında FDG işaretli lökosit $\mathrm{PET} /$ bilgisayarlı tomografinin (BT) tanısal rolünü araştırmışlardır (8). Pozitif FDG PET/BT çalışması olan 46 hastaya FDG işaretli lökosit PET/BT yapmışlardır. Ortalama işaretleme etkinliği \%75 \pm 17 olarak saptanmıştır. İ̧̧aretli lökosit canlılık testi ise yapılmamıştır. 296-703 MBq (8$19 \mathrm{mCi})$ FDG işaretli lökosit enjeksiyonundan yaklaşık 60-90 dakika sonra görüntüleme yapılmıştır. Çalışmaya sadece periprostetik FDG tutulumu olan hastalar dahil edildiğinden testin sadece pozitif öngörü değeri hesaplanabilmiş ve \%27 olarak bulunmuştur. Tersine FDG işaretli lökosit PET/BT'nin pozitif öngörü değeri \%93,3 olarak bulunmuştur. FDG işaretli lökosit PET/ BT için sensitivite, spesifite ve negatif öngörü değerleri sırasıyla \%93,3, \%97,4 ve \%97,4 olarak bildirilmiştir.

Bhattacharya ve ark. akut pankreatitli hastaların enfekte sIVı koleksiyonlarında FDG işaretli lökosit PET/ BT'nin tanısal rolünü araştırmışlardır (9). Ortalama işaretleme etkinliği \%81 $\pm 10 \quad(\% 31-97)$ olarak bulunmuştur. Tüm hastalarda işaretli lökosit canlıık oranı \%99'un üzerindedir. İşaretli hücrelerin enjeksiyonundan yaklaşık iki saat sonra görüntüleme yapılmış ve testin enfekte sıvı koleksiyonlarını saptamadaki doğruluk oranı \%100 olarak raporlanmıştır.

Yayınlarda FDG işaretli lökositlerin yararlı bir enfeksiyon görüntüleme ajanı olduğu belirtilse de bu prosedürün rutin klinik kullanıma geçirilmesi halinde yanıtlanması gereken sorular bulunmaktadır. Bunlardan ilki, FDG işaretli lökositlerin \%25'in altı ile \%90'ın üzerinde bir aralıkta değişen işaretleme etkinliğidir $(6,7,8,9,10)$. Bu değişkenlik göz önünde bulundurularak hücreleri işaretlemede ne kadar aktivite kullanılmalıdır? En kötü senaryoyu düşünürsek örneğin \%25 işaretleme etkinliği yeterli midir? Ya da işaretlenme etkinliği \%90'ın üzerinde ise neler olmaktadır? Enjekte edilecek aktivite de orantılı olarak azaltılmalı mıdır, eğer öyleyse tanısal veri elde edebilmek için enjekte edilen hücrelerin sayısı yeterli olacak mıdır?

Bir diğer konu da FDG'nin stabilitesidir. Yayınlara ait sonuçlar değişkenlik göstermektedir. Dumarey ve ark. işaretlemeden yaklaşık dört saat sonra \%90'lara varan bir ortalama stabilite değeri verirken Bhargava 
ve ark. tersine ilk bir saatte $\% 85 \pm 4$, dört saatte ise $\% 68 \pm 7$ 'ye düşen bir ortalama stabilite değerinden söz etmektedirler $(6,10)$. Kıyaslandığında, In-111 işaretli lökositlerin ortalama stabilitesi ise birinci saate $\% 94 \pm 2$; dördüncü saatte $\% 91 \pm 3$ ile her iki zaman diliminde de anlamlı olarak daha yüksek bulunmuştur.

İ̧aretleme etkinliği ve stabilite gibi sorunların üstesinden gelindiğini farz etsek de, F-18'in 110 dakika olan yarılanma ömrü kolayca çözülemeyecek lojistik problemlere neden olmaktadır. in vitro işaretleme prosedürü yaklaşık 2 ile 3 saat sürmektedir. Bu nedenle hücreleri işaretlemede kullanılacak aktivite miktarını belirlerken bu süre de göz önünde bulundurulmalıdır. F-18'in 110 dakikalık yarılanma ömrü, metodu tesis dışında uygulanmaya elverişsiz hale getirerek işaretlemeyi sadece belirli alanlarla sınırlandırmaktadır. $\mathrm{Bu}$; lökosit işaretleme prosedürlerinin çok büyük kısmının dış radyofarması laboratuvarlarında yapıldığı Birleşik Devletler'de çok önemli bir limitasyondur. Bazı durumlarda geç görüntü (örneğin; 24. saat gibi) alınması gerekebilmektedir. Böyle durumlarda F-18'in kısa yarılanma süresi enjeksiyondan 4-5 saat sonrası için görüntü alınabilmesini imkansız hale getirmektedir.

\section{Cu-64 İşaretli Lökositler}

Lökosit işaretleme için ideal bir radyonüklid, hücre canlıığını korurken aynı zamanda yüksek işaretleme etkinliğine sahip olmalıdır. İşaretleyici, hücrelerden olabildiğince az radyoaktivite elüsyonuna neden olarak stabil kalmalıdır. Ayrıca radyonüklidin yarılanma ömrü in vitro işaretlemeyi pratik olarak gerçekleştirebilecek ve geç görüntülemeye olanak sağlayacak kadar da uzun olmalıdır. Cu-64 yaklaşık 13 saatlik yarılanma ömrüne sahip orta yarı ömürlü bir pozitron yayıcı radyonüklidtir. Bhargava ve ark. bu radyonüklidin in vitro olarak lökosit işaretleme etkinliğini değerlendirmişlerdir (10). İnsan lökositlerini $\mathrm{Cu}-64$ ile in vitro olarak işaretlemişler ve işaretleme etkinliğini, hücre canlılığını ve bakır işaretli lökositlerin stabilitesini In-111 işaretli ve FDG işaretli lökositlerinki ile karşılaştırmışlardır. Cu-64 işaretli lökositlerin ortalama işaretleme etkinliği $\% 87 \pm 4$ ile In111 işaretli lökositler (\%86 \pm 4 ) ile benzer ve her ikisinin de işaretleme etkinliği FDG işaretli lökositlere (\%60 19$)$ oranla anlamlı olarak daha yüksek bulunmuştur. Birinci saatte her üçünün de hücre canlılığı benzer iken üçüncü ve yirmi dördüncü saatte $\mathrm{Cu}$-64'ün hücre canlılığı anlamlı olarak daha yüksek bulunmuştur. İşaretleme stabilitesi ise In-111 için her seferinde Cu-64 ve FDG'ye oranla anlamlı olarak daha yüksek saptanmıştır. Bu veriler ışığında Cu64 işaretli lökositlerin enfeksiyon görüntülemede yararlı olabileceği sonucuna varılabilir ancak bu konuyla ilgili bugüne kadar yapılmış klinik çalışma bulunmamaktadır. Kullanılan radyonüklid türüne bakılmaksızın, in vitro işaretleme prosedürü emeğe, teknik donanım ve kalifiye personele ihtiyaç duyulan, kanla doğrudan temas gerektiren ve her zaman el altında bulundurulamayan bir yöntemdir. Özellikle ciddi lökopenisi olan veya çok genç hastalarda tanısal optimal görüntülemeye olanak sağlayacak yeterli lökosit işaretleme mümkün olmayabilir. Locke ve ark. cFLFLFK-PEG isimli nötrofil spesifik bir peptidi Cu-64 ile işaretlemişlerdir (11). Bu peptid, nötrofil formil peptid reseptörünün antagonistidir. in vitro olarak işaretlenen peptid, insan nötrofillerine yüksek bağlanma afinitesi göstermiş ve daha önemlisi de hücreler üzerinde herhangi bir biyolojik etkiye neden olmamıştır. Locke ve ark. bu ajanı ayrıca Klebsiella pnömania ile oluşturulan sıçan modelinde de çalışmışlar ve işaretli peptidin enjeksiyonundan yaklaşık 18 saat sonra görüntüleme yapmışlardır (11). Klebsiella pnömania ile enfekte farelerde ortalama akciğer SUV değeri $0,142 \pm 0,054$ iken bu değer kontrol grubunda $0,028 \pm 0,003$ olarak bulunmuştur $(p<0,003)$. Preklinik veriler umut verici olsa da bu ajan ile yapılmış insan çalışması bulunmamaktadır.

\section{I-124 Fialuridin}

Radioiyodine edilmiş timidin analoğu olan fialuridin (FIAU) herpes simpleks virüs timidin kinaz (TK) ile transfekte edilmiş hücreler ve reporter genler için geliştirilmiştir. Bu enzim primidin deoksinükleoside adenozin trifosfattan bir fosfat grubu transfer eder. Lipofilik ajan hücre içine diffüzyonla girer ve burada TK aktivitesi sonucu oluşan fosforile form plazma membranından geçemediğinden hapsedilir (12). Bettegowda ve ark. bakterinin TK geni ile viral TK'nın birbirine son derece benzer olduğunu bu nedenle FIAU nun endojen bakteriyel TK tarafından da fosforile edilebildiğini belirtmişlerdir. Çalışmalarında, FIAU'nun "wild" tip bakteri büyümesini inhibe ederken, TK yetmezliği olan bakteri büyümesi üzerine hiç etki göstermediği sonucunu bulmuşlardır. Tek foton emisyonu yapan I-125 ile işaretli FIAU'yu kullanarak farelerde bakteriyel enfeksiyonu başarılı bir şekilde göstermişlerdir. Enfeksiyon odağında tutulum radyofarmasötik uygulanmasından dört saat sonra saptanmıştır. Araştırmacılar, FIAU'nun bakteriyel DNA'ya entegre olmasına bağlı olarak aktivitenin enfekte dokuda kaldığı sonucuna varmışlardır. Radyofarmasötik uygulanmasından sonraki 48 saat içerisinde enfekte 
olmayan dokudaki aktivite giderek azalarak hedef/geri plan aktivitesinin de artışa neden olmaktadır.

Pullambhatla ve ark. farelerde bakteriyel pulmoner enfeksiyon görüntülemede I-125 FIAU'nun rolünü araştırmışlardır (14). Enfekte akciğerlerde enjeksiyondan iki saat sonra tutulum saptanmış ve bu tutulum enfekte olmayan enflame akciğerlere ve kontrollere göre anlamlı olarak daha yüksek bulunmuştur. Antibiyotik tedavisi sonrası ise tutulumda anlamlı bir düşüş saptanmıştır. Araştırmacılar, radyoişaretli FIAU bakteriyel görüntülemenin yeni antibiyotiklerin geliştirilmesinde faydalı olabileceğini belirtmişlerdir.

Diaz ve ark. sekiz adet enfeksiyon şüphesi olan ve bir adet de sağlıklı kontrolden oluşan dokuz olguluk pilot çalışmalarında kas-iskelet sistemi enfeksiyonlarında I-124 FIAU PET/BT'nin tanısal rolünü araştırmışlardır (15). Görüntüleme öncesi en az üç hafta boyunca olguların hiçbiri antibiyotik tedavisi almamıştır. Enjeksiyondan iki saat sonra kas iskelet sistemi enfeksiyonu olan yedi olguda enfeksiyon alanında radyofarmasötik tutulumu gözlenmiştir. Enfeksiyonu olmayan bir olgu ile kontrol olgusunda ise anormal tutulum saptanmamıştır. Ayrıca dokuz olgunun hiçbirinde yan etkiye rastlanmamıştır.

Kas iskelet sistemi enfeksiyonlarında I-124 FIAU ile yapılan sonraki çalışmaların sonuçları ise hayal kırıklığı yaratmıştır. Zhang ve ark. görüntülemeden sonraki 30 gün içerisinde tamamı cerrahi yapılan alt ekstremite eklem artroplasti enfeksiyonu olan 19 hastada I-124 FIAU'nun tanısal rolünü retrospektif olarak araştırmışlardır (16). On dokuz hastanın sadece üç tanesi sonuçta enfeksiyon tanısı almıştır. Radyofarmasötik uygulamasından sonraki ikinci ve yirmi dördüncü saatlerde görüntüleme yapılmıştır. PET/ BT görüntülerinin değerlendirmesinde metale bağlı atenüasyon düzeltme artefaktlarına bağlı sıkıntılar yaşanmıştır. Atenüasyon düzeltmesi yapılmamış PET görüntülerinde ise diffüz, çok yoğun kas tutulumları izlenmiştir. Hedef/zemin "SUV max $_{\text {, }}$ SUV $_{\text {mean }}$, SUV $_{\text {peak" }}$ gibi enfekte protezleri enfekte olmayanlardan ayırmaya yarayan semikantitatif parametrelerden hiçbirisi kullanılmamıştır. Araştırmacılar sonuç olarak I-124 FIAU'nun prostetik eklem enfeksiyonlarındaki rolünün metal artefaktlarından kaynaklanan suboptimal görüntü kalitesi ve yüksek nonspesifik kas tutulumuna bağıı olarak oldukça sınırlı olduğu sonucuna varmışlardır. I-124 FIAU'nun diyabetik ayak enfeksiyonlarındaki tanısal rolünü değerlendiren bir diğer çalışmanın sonuçları da yine hayal kırıklı̆̆ı yaratmıştır. Çalışma I-124 FIAU tutulumu ile kemik biyopsi sonuçlarının korelasyon göstermemesi nedeniyle sonlandırılmıştır (17).

\section{Ga-68}

Ga-67 sitrat yaklaşık 50 yıldır enfeksiyon görüntülemede kullanılmaktadır. Ancak bu radyofarmasötiğin aseptik enflamasyon, tümör ve travma durumlarında nonspesifik tutulum göstermesi, ayrıca SPECT/BT ile çalışılmış olsa da görüntü kalitesinin suboptimal olması ve enjeksiyon ile görüntüleme arasında geçen sürenin 48 ile 72 saat gibi uzun süre gerektirmesi gibi dezavantajları bulunmaktadır. Ancak günümüzde pozitron emisyonu yapan Ga-68'in güncel kullanımı ile bu ajanın enfeksiyon görüntülemedeki rolünü araştıran çalışmalar yaygınlaşmıştır. Kumar ve ark. kemirgenlerde Stafilokokus aureus enfeksiyonlarını saptamada Ga-68 sitratın tanısal rolünü araştırmışlardır. Enjeksiyondan sonraki beş dakika içerisinde ortalama bir radyofarmasötik tutulumu gözlenmiş; 30 dakika ile altı saat içerisinde ise tutulum yoğun ve fokal hale gelmiştir. Ayrıca postoperatif intraabdominal enfeksiyonu olan bir hastada enjeksiyon sonrasında 30 dakika içerisinde testin pozitifleştiğini gözlemlemişlerdir. Tüberkülozlu hastalarla yapılan bir pilot çalışmada Ga-68'in pulmoner ve ekstapulmoner tüberküloz lezyonlarında tutulum gösterdiği ve ekstrapulmoner hastalığı saptamada BT'den üstün olduğu sonucu bulunmuştur. Araştırmacılar Ga-68'in aktif hastalığı inaktif hastalıktan ayırmada ve tedavi yanıtını değerlendirmede yardımcı olabileceği sonucuna varmışlardır (19).

Nanni ve ark. kas iskelet sistemi enfeksiyonu olan 31 hastaya 40 adet Ga-68 sitrat PET/BT çekimi gerçekleştirmişlerdir (20). Görüntülemeye radyofarmasötik enjeksiyonundan yaklaşık bir saat sonra başlanmıştır. Kas iskelet sistemi enfeksiyonu olan 23 hastanın tamamında pozitif sonuçlar alınırken enfeksiyonu olmayan 17 hastanın dört tanesi de pozitif olarak saptanmıştır. Bu yalancı pozitifliğin dört olgunun tamamında tümöre bağlı olduğu bulunmuştur. Sensitifite, spesifite, doğruluk, pozitif öngörü değeri ve negatif öngörü değerleri sırasıyla $\% 100, \% 76, \% 90, \% 85$ ve $\% 100$ olarak bulunmuşur.

Her ne kadar Ga-68 sitrat kullanımı ile Ga-67 sitratın düşük görüntü kalitesi, uygulama ile görüntüleme arasındaki uzun interval gibi dezavantajlarının üstesinden gelinmiş olsa da halen spesifitesinin sınırlı olması gibi dezavantajları bulunmaktadır $(20,21)$. Bunun sonucunda diğer araştırmacılar daha spesifik görüntüleme ajanları geliştirebilmek için dikkatlerini Ga-68 ile peptidleri kompleks haline getirme konusuna yönlendirmişlerdir (22). Vasküler adezyon protein 1 (VAP-1) enflamatuvar durumlarda hücre yüzeyinden eksprese edilen bir 
yüzey proteinidir. Lankinen ve ark. VAP-1'i hedef alan Ga-68 işaretli 1,4,7,10-tetraazacyclododecane-N',N", $\mathrm{N}^{\prime \prime \prime}, \mathrm{N}^{\prime \prime \prime \prime}$-tetraacetic asit-peptidin (Ga-68 DOTAVAP-P1) iyileşmekte olan kemiklerde erken enflamasyon ve enfeksiyonu göstermede faydalı olabileceği fikrini ortaya koymuşlardır (23). Araştırmacılar, 34'ünde enfekte olmayıp da iyileşmekte olan kortikal kemik defekti bulunan, 34'ünde ise Stafilokokus aureus osteomiyeliti olan toplam 68 farede Ga-68 DOTAVAP-P1 PET'i karşılaştırmışlardır. İyileşmekte olan kortikal kemik defekti bulunan hayvanlarda ortalama VAP1 ekspresyon düzeyi açısından 24. saatte ve 7 günde

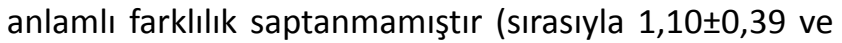
$1,00 \pm 0,47)$. Osteomiyeliti olan hayvanlarda ise ortalama VAP-1 ekspresyon düzeyi 7. günde $(2,85 \pm 0,34) 24$. saate $(2,39 \pm 0,49)$ oranla anlamlı olarak daha yüksek bulunmuştur $(p=0,0330)$. VAP-1 ekspresyon düzeyleri her iki zaman değerinde de enfekte hayvanlarda iyileşmekte olan kortikal kemik defekti olanlara oranla anlamlı olarak daha yüksek saptanmıştır $(p<0,0001)$. Ga-68 DOTAVAP-P1 tutulumu ise cerrahiden sonraki ilk 36 saat boyunca her iki grupta benzer olarak gözlenmiştir. İlk 36 saatten sonra ise tutulum sadece enfekte kemiklerde izlenmeye devam etmiştir. Yedinci günde Ga-68 DOTAVAP-P1 tutulumu enfekte kemiklerde anlamlı olarak daha yüksek bulunmuştur $(p<0,0001)$. Araştırmacılar Ga-68 DOTAVAP-P1'in iyileşmekte olan kemiklerdeki enflamatuvar fazı ve osteomiyelitli kemiklerde enfeksiyonun progresyonunu doğru şekilde gösterdiğini ve başlangıçtan sonraki 7 gün boyunca Stafilokokus aureus bağlı kemik enfeksiyonu gelişimi ile normal kemik iyileşmesi ayrımını kolaylaştırdığını belirtmişlerdir. Ujula ve ark. sağlıklı ve tibial Stafilokokus aureus enfeksiyonu olan sıçanlarda Ga-68 DOTAVAP-P1 PET görüntüleme yapmışlardır (24). Osteomiyelitteki radyofarmasötik tutulumu negatif kontrol peptid grubu ile kıyaslanmış ayrıca işaretlenmiş peptid ve işaretlenmemiş peptid kompetisyonu karşılaştırılmıştır. Ga-68 DOTAVAP-P1, VAP-1 ile transfekte olmuş hücrelere kontrollere oranla daha verimli bağlanma göstermiştir. Ajan dolaşımdan hızla temizlenmiş ve $26 \pm 2,3$ dakika gibi bir in vivo yarılanma süresi ile hızlıca idrar yoluyla atılmıştır. Enfekte kemiklerde orta derecede hedef/zemin oranı izlenmiştir. Ga-68 DOTAVAP-P1 ile kıyaslandığında negatif kontrol peptidi ve kompetitör ile olan çalışmalarda enfeksiyon alanında anlamlı olarak daha düşük tutulum gözlenmiştir. Araştırmacılar, bu çalışmanın Ga-68 DOTA peptid ile enfeksiyonun indüklediği VAP-1 ekspresyonunun gösterilebileceğini kanıtladığını belirtmişlerdir.
Ga-67'nin enfeksiyondaki tutulum mekanizması karmaşık olup halen anlaşılabilmiş değildir. Ancak bakteri tarafından üretilen galyum avid düşük molekül ağırlıklı selasyon ajanları olan sideroforlarla ilişkili olduğuna inanılmaktadır (25). Ga-68 işaretli sideroforların enfeksiyon görüntülemedeki potansiyeli araştırılmıştır $(26,27,28)$. Petrik ve ark. Aspergillus fumigatus kültürü kullanarak Ga-68 işaretli sideroforlar ile in vivo ve in vitro pek çok çalışma yapmışlardır (26). Kültürlerdeki tutulum demir yükü ve siderofor tipi ile ilişkili olarak bulunmuştur. Farelerde, Ga-68 triacetylfusarinine $C$ (TAFC) ve Ga-68 ferrioxamine $E$ (FOXE) hızlı kan klirensi ve renal ekskresyon göstermiştir. Ayrıca bu iki ajan Ga-68'e yüksek afinite ve stabilite ile bağlanmakta olup proteine bağlanma oranları düşüktür ve Aspergillus fumigatus için yüksek afinite ve spesifite göstermektedirler. Bu bulgular ışı̆̆ında bu iki ajanın Aspergillus enfeksiyonlarını göstermede yararlı olabileceği düşünülmektedir. Aspergillus akciğer enfeksiyonu oluşturulan bir sıçan modelinde, Petrik ve ark. Ga-68 TAFC ve Ga-68 FOXE'in her ikisinin de enfekte akciğer dokusunda oldukça yüksek selektif tutulum gösterdiğini ve tutulumun hastalığın ciddiyeti ile iyi korele olduğunu belirtmişlerdir (27). Petrik ve ark. Ga-68 TAFC ve Ga-68 FOXE'nin spesifitesini de araştırmışlardır (28). Bu amaçla çeşitli mantar, bakteri ve maya kültürleri ile insan akciğer kanseri hücrelerinde (H1299) bu 2 radyofarmasötiğin in vitro tutulumunu değerlendirmişlerdir. İn vivo görüntülemeyi de fungal ve bakteriyel enfeksiyon ve enflamasyon oluşturulan sıçan modelleri ile değerlendirmişlerdir. Ga-68 TAFC ve Ga-68 FOXE, Aspergillus fumigatus kültürlerinde hızlıca akümüle olmuş, ancak diğer mantar türlerinde tutulum anlamlı olarak daha düşük bulunmuştur. Diğer mikroorganizmalar ile H1299 hücrelerinde minimal tutulum gözlenmiş olup bunun tek istisnası Stafilokokus aureus'ta izlenen Ga-68 FOXE tutulumudur. Aspergillus fumigatus ile enfekte olmuş sıçan akciğerlerinde her iki ajan da hızlıca tutulum göstermiş olup steril enflamasyonda düşük tutulum saptanmış, bakteriyel abselerde ise hiç tutulum saptanmamıştır.Ga-68 FOXE daha sensitif iken Ga-68 TAFC daha spesifik olarak değerlendirilmiştir. Antimikrobiyal peptidler çoğu canlı organizmanın doğal savunma sisteminin önemli bir parçasıdır. Çoğu küçük, katyonik ve amfipatik (hidrofilik ve hidrofobik) olup patojenlerle çeşitli mekanizmalar üzerinden mücadele ederler. Gram pozitif ve Gram negatif bakteriler, mayalar, mantarlar ve zarflı virüslere karşı geniş bir spektrumda aktivite gösterirler. Ayrıca apopitozis, yara iyileşmesi ve immün modülasyon ile de 
ilişkilidirler (29). Antimikrobiyal peptidlerle yapılmış pek çok çalışmada radyoişaretleyici olarak Tc-99m kullanılmış olsa da son dönemde Ga-68 işaretli antimikrobiyal peptidlerin enfeksiyon spesifik görüntüleme bileşikleri olarak kullanımı üzerine araştırmalar yaygınlaşmaktadır $(30,31,32)$. Ebenhan ve ark. ubiquisidinin UBI2941 fragmanını Ga-68 ile işaretleyerek bu ajanın tutulumunu tavşanlarda oluşturulan Stafilokokus aureus kas enfeksiyonu, terebentin ile indüklenmiş kas enflamasyonu ve yumurta albümini ile indüklenmiş akciğer enflamasyonlarında karşılaştırmışlardır (31). Enjeksiyon sonrası iki saate kadar olan intervallerde de PET/BT çekimini gerçekleştirmişlerdir. Enfekte uyluk kası steril enflamasyon gösteren uyluk kasından net bir şekilde ayırt edilebilmiştir. Akciğerlerde yumurta albümini ile indüklenerek oluşturulan enflamasyonda belirgin, anlamlı bir tutulum saptanmamıştır. Elde edilen sonuçlar Ga-68 işaretli UBI29-41 ile enfeksiyon ile steril enflamasyon ayrımının potansiyel olarak yapılabileceği yönündedir. Son dönemde Mokaleng ve ark. bir antimikrobiyal peptid derivesi olan TBIA 101'i DOTA ile bağlayıp Ga-68 ile işaretleyerek enfeksiyon görüntülemedeki potansiyelini araştırmışlardır (32). Ga68DOTA-TBIA 101 mikro PET/BT farelerde Escherichia coli ile oluşturulan kas enfeksiyonlarının görüntülemesinde kullanılmıştır. Radyofarmasötik tutulumu enfekte uyluk kasında $(p=0,333)$ enfekte olmayan uyluk, ön kol $(p=0,092)$ kasına ve geri plan aktivitesine $(p=0,021)$ oranla anlamlı olarak daha yüksek bulunmuştur. Ga68 DOTA-TBIA 101 ile enfeksiyon alanı net bir şekilde lokalize edilirken karşı taraf kaslarda belirgin bir tutulum saptanmamıştır.

\section{Sonuç}

FDG PET'in enfeksiyon ve enflamasyon tanısındaki değeri iyi bilinmektedir. Bu radyofarmasötiğin en önemli limitasyonu spesifitesinin düşük olmasıdır. Araştırmacılar PET'in tek foton emisyonu yapan radyofarmasötiklere göre avantajından da yararlanarak enfeksiyon için spesifitesi yüksek PET ajanları geliştirmeye çalışmışlardır. Bu amaçla yapılan ilk çalışmalarda lökositlerin PET radyonüklidleri ile in vitro işaretlenmesi üzerine odaklanılmıştır. Her ne kadar bu konuda yapılan çalışmaların sonuçları umut verici olsa da pek çok nedenden dolayı kullanımı yaygınlaşmamıştır ve yaygınlaşacak gibi de görünmemektedir. Dahası, işaretli lökositler lökosit migrasyonunu göstermede spesifik olsalar da enfeksiyon için gerçek anlamda spesifik değillerdir. I-124 FIAU ile yapılan ilk çalışmaların sonuçları bu ajanın enfeksiyona spesifik olduğunu düşündürecek şekilde umut verici olsa da son veriler bu ajan için duyulan heyecanı azaltır niteliktedir. Ga-68 ile işaretli sideroforlar ve antimikrobiyal peptidler ile yapılan son çalışmaların ön verileri heyecan uyandırmakla birlikte bu verileri destekleyecek, kesinleştirecek klinik çalışmalar gerekmektedir.

\section{Kaynaklar}

1. Osman S, Danpure HJ. The use of 2-[18F]Fluoro-2-deoxyD-glucose as a potential in vitro agent for labelling human granulocytes for clinical studies by positron emission tomography. Nucl Med Biol 1992;19:183-190.

2. Forstrom LA, Mullan BP, Hung JC, Lowe VJ, Thorson LM. 18-FDG labeling of human leukocytes. Nucl Med Commun 2000;21:691-694.

3. Forstrom LA, Dunn WL, Mullan BP, Hung JC, Lowe, VJ, Thorson LM. Biodistribution and dosimetry of 18Ffluorodeoxyglucose labeled leukocytes in normal human subjects. Nucl Med Commun 2002;23:721-725.

4. Pellegrino D, Bonab AA, Dragotakes SC, Pitman JT, Mariani G, Carter EA. Inflammation and infection: Imaging properties of 18F-FDG-labeled white blood cells versus 18F-FDG. J Nucl Med 2005;46:1522-1530.

5. Pio BS, Byrne FR, Aranda R, et al. Noninvasive quantification of bowel inflammation through positron emission tomography imaging of 2-deoxy-2-2[18F]fluoro-D-glucose-labeled white blood cells. Mol Imaging Biol 2003;5:271-277.

6. Dumarey N, Egrise $D$, Blocklet $D$, et al. Imaging infection with 18F-FDG-labeled leukocyte PET/CT: initial experience in 21 patients. J Nucl Med 2006;47:625-632.

7. Rini JN, Bhargava KK, Tronco GG, et al. PET with FDGlabeled leukocytes versus scintigraphy with 111/n-oxinelabeled leukocytes for detection of infection. Radiology 2006;238:978-987.

8. Aksoy SY, Asa S, Ozhan M, et al. FDG and FDG-labelled leucocyte PET/CT in the imaging of prosthetic joint infection. Eur J Nucl Med Mol Imaging 2014;41:556-564.

9. Bhattacharya $A$, Kochhar R, Sharma $S$, et al. PET/CT with 18F-FDG-labeled autologous leukocytes for the diagnosis of infected fluid collections in acute pancreatitis. J Nucl Med 2014;55:1267-1272.

10. Bhargava KK, Gupta RK, Nichols KJ, Palestro CJ. In-vitro human leukocyte labeling with (64)Cu: an intraindividual comparison with (111)In-oxine and 18F-FDG. Nucl Med Biol 2009;36:545549.

11. Locke LW, Chordia MD, Zhang Y, et al. A novel neutrophilspecific PET imaging agent: cFLFLFK-PEG-64Cu. J Nucl Med 2009;50:790-797.

12. Boerman OC, Laverman P, Oyen WJ. FIAU: from reporter gene imaging to imaging of bacterial proliferation. Am J Nucl Med Mol Imaging 2012;2:271-272. 
13. Bettegowda C, Foss CA, Cheong I, et al. Imaging bacterial infections with radiolabelled 1-(2'-deoxy-2'fluoro- $\beta$-Darabinofurasonyl)-5-iodouracil. Proc Natl Acad Sci U S A 2005;102:1145-1150.

14. Pullambhatla M, Tessier J, Beck G, Jedynak B, Wurthner JU, Pomper MG. [125I]FIAU imaging in a preclinical model of lung infection : quantification of bacterial load. Am J Nucl Med Mol Imaging 2012;2:260-270.

15. Diaz LA Jr, Foss CA, Thornton $K$, et al. Imaging of musculoskeletal bacterial infections by [124I]FIAU-PET/CT. PLoS One 2007;10:e1007.

16. Zhang XM, Zhang HH, McLeroth P, et al. [124I]FIAU: Human dosimetry and infection imaging in patients with suspected prosthetic joint infection. Nucl Med Biol 2016;43:273-279.

17. [124I]FIAU-PET/CT scanning in diagnosing osteomyelitis in patients with diabetic foot infection.clinicaltrials.gov/ct2/show/ NCT01764919. Updated April 6, 2016. Accessed August 13, 2016.

18. Kumar V, Boddeti DK, Evans SG, Angelides S. (68)Ga-citrate-PET for diagnostic imaging of infection in rats and for intra-abdominal infection in a patient. Curr Radiopharm 2012;5:71-75.

19. Vorster M, Maes A, Van de Wiele C, Sathekge MM. 68Gacitrate PET/CT in Tuberculosis: A pilot study. Q J Nucl Med Mol Imaging 2014 Mar 20. [Epub ahead of print]

20. Nanni C, Errani C, Boriani L, et al. 68Ga-citrate PET/CT for evaluating patients with infections of the bone: preliminary results. J Nucl Med 2010;51:1932-1936.

21. Vorster $M$, Maes A, Jacobs A, et al. Evaluating the possible role of $68 \mathrm{Ga}$-citrate $\mathrm{PET} / \mathrm{CT}$ in the characterization of indeterminate lung lesions. Ann Nucl Med 2014;28:523-530.

22. Roivainen A, Jalkanen S, Nanni C. Gallium-labelled peptides for imaging of inflammation. Eur J Nucl Med Mol Imaging 2012;39(Suppl 1):68-77.

23. Lankinen P, Mäkinen TJ Pöyhönen TA, et al. (68)GaDOTAVAP-P1 PET imaging capable of demonstrating the phase of inflammation in healing bones and the progress of infection in osteomyelitic bones. Eur J Nucl Med Mol Imaging 2008;35:352-364.
24. Ujula T, Salomäkia S, Virsua P, et al. Synthesis, $68 \mathrm{Ga}$ labeling and preliminary evaluation of DOTA peptide binding vascular adhesion protein-1: a potential PET imaging agent for diagnosing osteomyelitis. Nucl Med Biol 2009;36:631641.

25. Palestro CJ. Continuing education on radionuclide imaging of musculoskeletal infection: a review. J Nucl Med 2016.

26. Petrik $M$, Haas $H$, Schrettl $M$, Helbok $A$, Blatzer $M$, Decristoforo $C$. In vitro and in vivo evaluation of selected 68Ga-siderophores for infection imaging. Nucl Med Biol 2012;39:361-369.

27. Petrik $M$, Franssen $G M$, Haas $H$, et al. Preclinical evaluation of two $68 \mathrm{Ga}$-siderophores as potential radiopharmaceuticals for Aspergillus fumigatus infection imaging. Eur J Nucl Med Mol Imaging 2012;39:1175-1183.

28. Petrik $M$, Haas $H$, Laverman $P$, et al.68Ga-triacetylfusarinine $\mathrm{C}$ and 68Ga-ferrioxamine $\mathrm{E}$ for Aspergillus infection imaging: uptake specificity in various microorganisms. Mol Imaging Biol 2014;16:102-108.

29. Wang G. Human antimicrobial peptides and proteins. Pharmaceuticals (Basel) 2014;7:545-594.

30. Ebenhan T, Chadwick N, Sathekge MM, et al. Peptide synthesis, characterization and ${ }^{68} \mathrm{Ga}$-radiolabeling of NOTAconjugated ubiquicidin fragments for prospective infection imaging with PET/CT. Nucl Med Biol 2014;41:390-400.

31. Ebenhan T, Zeevaart JR, Venter JD, et al. Preclinical evaluation of 68Ga-labeled 1,4,7-triazacyclononane-1,4,7-triacetic acidubiquicidin as a radioligand for PET infection imaging. J Nucl Med 2014;55:308-314.

32. Mokaleng BB, Ebenhan T, Ramesh S, et al. Synthesis, 68Ga-radiolabeling, and preliminary in vivo assessment of a depsipeptide-derived compound as a potential PET/CT infection imaging agent. Biomed Res Int 2015;2015:284354. 